\title{
BRAF/EGFR Inhibitor BGB-283
}

National Cancer Institute

\section{Source}

National Cancer Institute. BRAF/EGFR Inhibitor BGB-283. NCI Thesaurus. Code C124995.

An inhibitor of the serine/threonine protein kinase B-raf (BRAF) and epidermal growth factor receptor (EGFR), with potential antineoplastic activity. Lifirafenib selectively binds to and inhibits the activity of BRAF and certain BRAF mutant forms, and EGFR. This prevents BRAF- and EGFR-mediated signaling and inhibits the proliferation of tumor cells that either contain a mutated BRAF gene or express over-activated EGFR. In addition, BGB283 inhibits mutant forms of the Ras proteins K-RAS and N-RAS. BRAF and EGFR are mutated or upregulated in many tumor cell types. 